\title{
PENERAPAN MODEL PEMBELAJARAN KOOPERATIF TIPE THINK PAIR SHARE UNTUK MENINGKATKAN PRESTASI BELAJAR IPS SISWA KELAS V SDI ENDE 14
}

\author{
Berty Sadipun \\ Universitas Flores \\ E-mail: bertysadipun@gmail.com
}

\begin{abstract}
The objectives achieved in this research are to find out the use of think pair share type cooperative learning models in Social Studies learning of Artificial Appearance in Indonesia, to find out the increase in students' learning achievement by using cooperative learning models of think pair share type in SDI Ende 14 Ende Timur district, Ende Regency. This type of research is Classroom Action Research, with a qualitative approach to grade 5 students of SDI Ende 14. Data collection techniques in this study were observation, interviews, learning outcomes tests and documentation. Data analysis uses descriptive qualitative data analysis techniques. Based on the results of the evaluation of the first cycle with a percentage of completeness of $54 \%$ and an average of $57.45 \%$, the results of the evaluation of the second cycle with a percentage of completeness of $100 \%$ with an average of 90\%, the application of the cooperative learning model type think pair share with the material appearance made in Indonesia can improve student learning achievement.
\end{abstract}

Keywords: think pair share model; learning achievement.

\begin{abstract}
ABSTRAK
Penelitian ini bertujuan untuk mengetahui pemahaman struktur kalimat dengan melibatkan unsur pemahaman (comprehension) dan pemroduksian (production) yang berkaitan erat dengan kajian performa pembelajaran bahasa, terutama dalam pembelajaran bahasa asing. Penelitian ini menggunakan metode kuantitatif yang dilakukan terhadap 33 pelajar bahasa Inggris untuk mengetahui sejauh mana peserta memahami struktur kalimat bahasa Inggris sederhana yang terkait dengan kemampuan mereka menghasilkan kalimat bahasa Inggris. Data penelitian diperoleh melalui 2 macam tes. Data tentang pemahaman adalah dalam bentuk tes cloze benar atau salah dari total 50 kalimat sederhana dengan struktur argumen. Sedangkan data produksi berupa tes tertulis konstruksi kalimat sederhana berdasarkan gambar dan instruksi tentang gambar. Kedua tes menggunakan sejumlah kata kerja yang paling sering diingat oleh mahasiswa Jurusan Bahasa Inggris, Universitas Darma Persada. Hasil penelitian menunjukkan bahwa tingkat pemahaman mereka adalah $65,64 \%$ dengan variasi dalam skor distribusi antara mereka adalah 8,79, dan produksi mereka adalah 28,36\% dengan standar deviasi produksi 17,37. Kesenjangan antara tingkat pemahaman dan tingkat produksi relatif besar yang berarti bahwa kompetensi produksi rata-rata subjek berada di bawah kompetensi pemahaman peserta didik.
\end{abstract}

Kata kunci: model think pair share; prestasi belajar.

\section{PENDAHULUAN}

Belajar pada hakikatnya adalah
interaksi antara lingkungan dan
pengalaman seseorang dalam proses
mengubah tingkah laku (Slameto, 2002:

2). Proses perubahan tersebut salah satunya dalam bentuk prestasi belajar.
Oleh karena itu, prestasi belajar cenderung diartikan sebagai ukuran dari kualitas pembelajaran (Jumrah dan Afni, 2019). Problematika yang menyangkut prestasi belajar merupakan hal yang kerap dialami oleh semua peserta didik. Kondisi ini pun berlaku pada peserta didik kelas V SDI

Cara mengutip: Sadipun, B. (2020). Penerapan Model Pembelajaran Kooperatif Tipe Think Pair Share untuk Meningkatkan Prestasi Belajar IPS Siswa Kelas V SDI Ende 14. Inteligensi: Jurnal Ilmu Pendidikan, 3(1), 11-16 
Ende 14. Rendahnya prestasi siswa tersebut disebabkan banyak hal seperti, guru kurang memberikan stimulus yang melibatkan siswa dalam proses berpikir dan bekerjasama. Siswa cenderung mendengar dan mencatat hal-hal penting yang disampaikan oleh guru sehingga terkesan pasif. Guru juga jarang melakukan refleksi pembelajaran sehingga tidak menggali dan memperbaiki factor penyebab rendahnya prestasi belajar.

Setiap permasalahan pembelajaran memiliki jalan keluar. Salah satu cara untuk meningkatkan kualitas pembelajaran adalah dengan mempertimbangkan strategi pembelajaran yang akan dipakai dengan tingkat pengetahuan peserta didik. Pemilihan model think pair share (TPS) merupakan salah satu alternative dalam menjawabi permasalahan tersebut. Alasan mengapa model pembelajaran TPS karena model pembelajaran ini telah terbukti dapat meningkatkan prestasi belajar siswa. Hal ini terpapar dalam hasil penelitian Nurnawati (2012), Zulfah (2017) dan Ni'mah (2014). Hasil penelitian-penelitian tersebut memberikan masukan bahwa TPS dapat diterapkan dalam pembelajaran karena dapat meningkatkan prestasi belajar.

Dengan menerapkan model pembelajaran kooperatif tipe Think Pair Share siswa dapat dilibatkan dalam proses berpikir dan saling bekerjasama dalam menyelesaikan masalah ataupun persoalan yang diberikan oleh guru. Menurut Trianto model Think Pair Share (TPS) atau berpikir berpasangan berbagi merupakan jenis pembelajaran kooperatif yang dirancang untuk mempengaruhi pola interaksi siswa (Rianingsih dkk, 2019). Model ini juga efektif untuk membuat pola diskusi kelas lebih bervariasi (Arends dalam Huda, 2013: 207). Dengan demikian dapat disimpulkan bahwa model Think Pair Share adalah pembelajaran kooperatif yang mengedepankan proses kerjasama dalam berpikir dan berinteraksi dalam memecahkan suatu permasalahan.

Keunggulan model Think Pair Share yaitu dapat membangun suasana belajar yang komunikatif antar siswa dimana siswa saling berbagi informasi kepada siswa lain yang masih dalam kelompoknya (Rianingsih dkk., 2019). Model TPS juga memberikan kesempatan kepada siswa untuk mengembangkan proses berpikir dan saling menyampaikan idenya dalam menyelesaikan permasalahan. Dalam hasil penelitian lain, model ini juga efektif terhadap aktivitas belajar siswa di kelas (Indriani, 2014).

Memilih model pembelajaran kooperatif tipe Think Pair Share dapat meningkatkan prestasi belajar peserta didik (Jasdilla dkk, 2017). Mengajukan permasalahan dan memberikan kesempatan kepada siswa untuk memikirkan jawaban beberapa saat, kemudian membagi jawabannya dengan pasangan atau dengan anggota tim lainnya melalui dialog berpasangan. Secara eksplisit langkah di dalam model tersebut memberi kesempatan bagi siswa untuk berpikir, menjawab dan saling membantu satu sama lain. Model Think Pair Share merupakan jenis pembelajaran kooperatif dimana siswa dapat berpikir, berbagi dan bekerja sama dengan orang lain (Trianto dalam Yustitia dkk, 2018). Proses berpikir yang merupakan salah satu langkah dalam model ini memberikan ruang bagis siswa untuk dapat mengembangkan kemampuan mengungkapkan ide atau gagasan. Siswa juga dapat membandingkan ide-idenya 
dengan orang lain melalui kerjasama antar anggota kelompok (Indriani, 2014).

Model ini mengedepankan siswa untuk berperan aktif bersama dengan teman kelompoknya dengan cara berdiskusi untuk memecahkan suatu permasalahan (Lie dalam Yustitia dkk, 2018). Siswa saling menyampaikan idenya dalam menyelesaikan permasalahan bersama dengan teman kelompoknya. Keadaan ini membuat siswa lebih aktif dalam mengikuti proses pembelajaran yang nantinya akan berpengaruh pada prestasi belajar sebagai hasil yang diperoleh seseorang setelah menempuh kegiatan belajar. Prestasi belajar dikatakan sempurna apabila memenuhi tiga aspek yakni: kognitif, affektif dan psikomotor, sebaliknya dikatakan prestasi kurang memuaskan jika seseorang belum mampu memenuhi target dalam ketiga kriteria tersebut (Mulyasa, 2013:189).

Bloom dalam Syah (2001:21) membagi tingkat prestasi belajar siswa ke dalam tiga ranah yakni ranah kognitif, afektif dan psikomotorik. Ranah kognitif menurut Bloom terdiri atas enam hierarki yakni pengetahuan, pemahaman, penerapan, analisis, sintesis dan evaluasi. Hierarki tersebut kemudian direvisi menjadi mengingat, memahami, menerapkan, menganalisis, mengevaluasi dan mencipta (Setiawan, 2018). Ranah afektif merupakan proses pengetahuan yang berdasarkan aspek-aspek perasaan dan emosi. Kratwohl dkk (Sukardi, 2008:23) membed an ranah afektif ke dalam lima tingkatan yaitu a) receiving, b) responding, c)valuing, d) organizing, e) characterization by value or complex.

$$
\text { Adapun ranah psikomotor }
$$
berhubungan dengan keterampilan siswa (Ain dan Kurniawati, 2013). Dalam ranah ini terdiri atas empat tingkatan yakni 1) Imitasi, 2) Manipulasi, 3) Presisi, 4) Akurasi. Dengan demikian, berdasarkan problematika pembelajaran IPS yang terjadi di kelas V SDI Ende 14, maka sangat tepat untuk diterapkan model TPS untuk dapat meningkatkan prestasi belajar siswa.

\section{METODE PENELITIAN}

Jenis penelitian yang dilakukan adalah jenis Penelitian Tindakan Kelas (PTK). PTK memberi ruang bagi guru agar bisa memperbaiki cara mengajar yang baik agar prestasi belajar peserta didik lebih meningkat. (Ningrum, 2014: 25). Adapun prosedur penelitian tindakan kelas yang dipergunakan dalam penelitian ini adalah menggunakan model Kammis dan McTaggart yang terdiri atas tahap perencanaan, observasi, tindakan dan refleksi.

Subyek penelitian adalah kelas V Sekolah Dasar Inpres Ende 14 Kecamatan Ende Timur, Kabupaten Ende yang berjumlah 24 orang. Adapun teknik pengumpulan data terdiri atas observasi, tes dan dokumentasi. Observasi dilakukan untuk menangkap data tentang pelaksanaan penerapan model TPS, data aktivitas guru dan data aktivitas siswa. Teknik tes dilakukan untuk mengetahui data prestasi belajar. sedangkan dokumentasi untuk mengambil data tentang keadaan sekolah, perangkat pembelajaran, foto-foto selama pembelajaran berlangsung, serta dokumendokumen lain yang dapat dijadikan data pendukung dalam penelitian ini. Data-data tersebut dianalisis dengan cara reduksi data, penyajian data dan penarikan kesimpulan. 


\section{HASIL DAN PEMBAHASAN}

Berdasarkan hasil penelitian selama dua siklus, telah diterapkan model TPS melalui langkah-langkah sebagai berikut:

a) Guru menjelaskan secara garis besar materi tentang Kenampakan Buatan di Indonesia

b) Guru membagi peserta didik dalam bentuk kelompok.

c) Setiap kelompok terdiri dari 4- 6 orang peserta didik.

d) Guru memberikan pertanyaan kepada siswa kemudian siswa diberikan waktu untuk berpikir.

e) Siswa berpikir untuk memperoleh jawaban.

f) Siswa diminta untuk berpasangan dengan temannya,

g) Siswa berdiskusi dengan pasangannya untuk memecahkan pertanyaan guru, peneliti membimbing pserta didik dalam mengerjakan soal.

h) Siswa menyampaikan hasil diskusinya di depan kelas,

i) Guru memberikan kesimpulan dan meluruskan jawaban siswa dan menambah jawaban siswa.

Dalam menerapkan model tersebut, dilakukan observasi terhadap aktivitas guru dan aktivitas siswa. pada siklus I ditemukan persentase aktivitas guru sebesar 57\% dengan kategori cukup aktif, sedangkan aktivitas siswa sebesar $42 \%$ dan dalam kategori cukup aktif. siklus II, aktivitas guru dan siswa tersebut meningkat berturut-turut menjadi $71 \%$ dan $92 \%$, atau berada dalam kategori aktif dan sangat aktif. adapun data persentase prestasi belajar yang diperoleh melalui tes siklus I sebesar $54 \%$. Perolehan prestasi belajar pada siklus I terebut belum memenuhi indicator kinerja dalam penelitian ini sehingga perlu dilanjutkan pada siklus II. Sedangkan perolehan persentase prestasi belajar pada siklus II sebesar $100 \%$ dan telah memenuhi indicator kinerja, sehingga penelitian dihentikan pada siklus II.

Berdasarkan deskripsi awal pembelajaran Ilmu Pengetahuan Sosial di kelas V SDI Ende 14 ditemukan pemasalahan mengenai rendahnya prestasi belajar siswa. Hal ini didukung dengan proses belajar mengajar di kelas. Siswa cenderung mendengar dan mencatat hal-hal penting yang disampaikan oleh guru sehingga terkesan pasif. Begitupun guru kurang memberikan stimulus yang melibatkan siswa dalam proses berpikir dan bekerjasama. Pemberian stimulus sangat dianjurkan dalam kegiatan belajar. Menurut Yudianto (2012), pemberian stimulus dapat meningkatkan pengetahuan dan sikap anak terhadap permasalahan di sekitarnya.

Kelemahan lain yang ditemukan adalah Guru tidak mengikuti langkahlangkah yang sudah disiapkan dalam RPP. Hal ini dikarenakan guru jarang melakukan refleksi pembelajaran sehingga tidak menggali dan memperbaiki factor penyebab rendahnya prestasi belajar. Menurut (Lisiswanti, 2013), refleksi sangat penting untuk dilakukan seorang pendidik sebab refleksi bermanfaat dalam mengembangkan professional pendidik dan peserta didik. Melalui refleksi dapat menghasilkan tindakan yang lebih baik pada proses belajar selanjutnya.

Untuk mengatasi masalah tersebut, maka peneliti merencanakan penerapan model pembelajaran yang dapat membuat peserta didik aktif dan berpikir kritis 
dalam proses pembelajaran yaitu menerapkan model pembelajaran kooperatif tipe think pair share. Berdasarkan temuan dalam penelitian ini maka model pembelajaran Think Pair Share sangat cocok untuk diterapkan untuk meningkatkan hasil belajar siswa. Menurut Isjoni (2011: 64), model TPS sebagai bagian dari pembelajaran kooperatif dirancang untuk mempengaruhi pola interaksi siswa. model pembelajaran think pair share merupakan model pembelajaran yang membuat siswa lebih aktif dan terlibat dalam belajar kelompok yaitu dengan cara guru memberikan soal kepada peserta didik, kemudian peserta didik berpikir secara berpasangan dan berbagi pendapat dengan pasangan yang lainnya (Komalasari, 2015: 64). Berdasarkan kelebihan model ini maka diterapkanlah model TPS pada pembelajaran IPS di kelas V SDI Ende 14. Setelah diterapkan model TPS, prestasi belajar peserta didik mengalami peningkatan. Hal ini dapat dilihat pada pencapaian hasil tes siklus I yang mencapai ketuntasan 57,45\% dan pada siklus II mengalami kenaikan $92 \%$ sehingga peserta didik mengalami ketuntasan maksimal sebagai mana yang diinginkan oleh peneliti yakni $100 \%$.

Pencapaian peningkatan hasil belajar juga konsisten dengan peningkatan aktivitas guru maupun siswa di dalam kelas. Proses belajar tidak terkesan searah lagi, namun terjadi dua arah antar siswa dan guru. Hal ini teramati pada perolehan persentase aktivitas guru maupun aktivitas siswa selama dua siklus. ditemukan persentase aktivitas guru sebesar 57\% dengan kategori cukup aktif, sedangkan aktivitas siswa sebesar $42 \%$ dan dalam kategori cukup aktif. Siklus II, aktivitas guru dan siswa tersebut meningkat berturut-turut menjadi $71 \%$ dan $92 \%$, atau berada dalam kategori aktif dan sangat aktif.

\section{SIMPULAN}

Penelitian ini bertujuan untuk meningkatkan prestasi belajar siswa kelas V SDI Ende 14 dengan menerapkan model think pair share. Setelah diterapkan model tersebut ditemukan adanya peningkatan prestasi belajar siswa dari iklus I sebesar $57,45 \%$ menjadi $100 \%$ pada siklus II.

\section{DAFTAR PUSTAKA}

Ain, N. dan Kurniawati, M. 2013. Implementasi Kurikulum KTSP: Pembelajaran Tematik Di Sekolah Dasar. Jurnal Inspirasi Pendidikan 3, 2.

Huda, M. 2013. Model-model Pembelajaran. Yogyakarta : Celeban Timur.

Isjoni. 2011. Cooperative Learning. Bandung: Alfabeta.

Indriani, D.S. 2010. Keefektifan Model Think Pair Share Terhadap Aktivitas Dan Hasil Belajar IPS. Journal of Elementary Education (3)2.

Jasdila, L., dkk. 2017. Hasil belajar dan Pembelajaran kooperatif tipe think Pair Share. Jurnal Pendidikan Indonesia 6 (1).

Jumrah, A.M., dan Afni, N. 2019. Penerapan Model Kooperatif Tipe Think Pair Share (TPS) dalam meningkatkan hasil belajar IPS pada siswa kelas V SD Inpres Punranga kecamatan Pujananting Kabupaten Barru. Dikdas Matappa: Jurnal Ilmu Pendidikan Dasar 2, 2.

Komalasari, K. 2015. Pembelajaran Kontekstual. Bandung: PT Refika Aditama 
Lisiswanti, R. 2013. Refleksi. Tersedia: http://repository.lppm.unila.ac.id/ 3287/1/REFLEKSI\%20ARTIKEL $\% 20 \% 28$ dr.Rika\%20L\%29\%20E DITjjuke.pdf

Mulyasa, E. 2013. Pengembangan dan implentasi pemikiran kurikulum. Bandung: Rosdakarya.

Ni'mah, A. 2014. Penerapan Model Pembelajaran Think Pair Share (TPS) dengan metode Eksperimen untuk Meningkatkan Hasil Belajar dan Aktivitas Belajar Siswa Kelas VIII MTS Nahdlatul Muslimin Kudus. (Skripsi). Tersedia: Lib.unnes.ac.id.

Nurnawati, E. dkk. 2012. Peningkatan kerjasma siswa SMP melalui Penerapan Pembelajaran Kooperatif Pendekatan Think pair Share. UPEJ Unnes Physics Education Journal 1, 1.

Slameto. 2010. Belajar \& Faktor-faktor yang Mempengaruhi. Jakarta: Rineka Cipta.

Syah, M. 2001. Psikologi Pendidikan dengan Pendekatan Baru. Bandung: Remaja Rosdakarya.

Rianingsih, A., Mawardi dan Wardani, K.W. 2019. Penerapan Model Pembelajaran TPS (Think Pair Share) dalam Rangka Meningkatkan Keterampilan Komunikasi Siswa Kelas 3. Jurnal Kajian Penelitan dan Pendidikan dan Pembelajaran 3, 2.

Setiawan, D.F. 2018. Menerapkan Revision Bloom's Taxonomy Pada Tujuan Pembelajaran Umum Ranah Kognitif Kajian Persamaan
Dasar Akuntansi. Jurnal Ilmiah Pendidikan Ekonomi 3, 2.

Sukardi. 2008. Evaluasi Pendidikan (Prinsip dan Operasionalnya). PT Bumi Aksara. Jakarat Timur.

Triana, N. 2019. Penerapan Metode Paired Reading/ Paired Summarizing untuk Meningkatkan Kemampuan Pemahaman Membaca Teks pada Siswa SMK Abdurrab Pekanbaru. Inteligensi: Jurnal Ilmu Pendidikan, 2(1), 3338.

Zulfah, Z. 2017. Pengaruh Penerapan Model Pembelajaran kooperatif tipe think Pair Share dengan pendekatan Heuristik Terhaadap kemampuan Pemecahan Masalah Matematis Siswa MTs Negeri Naumbai. Jurnal Cendekia: Jurnal Pendidikan Matematika 1, 2.

Yudianto, A., Mukarromah I., \& Yani, A.L. 2012. Pengaruh Stimulasi Permainan Ular Tangga Terhadap Perubahan Sikap Siswa Tentang Demam Berdarah Dengue. Prosiding Seminas Competitive Advantage. Tersedia: http://journal.unipdu.ac.id:8080/ind ex.php/seminas/article/view/157/10 2

Yustitia, V., Rusminati, S.H., \& Sulistyawati, I. 2014. Implementasi Lesson Study Menggunakan Model Think Pair Share Dan Pendekatan Saintifik. Premiere Educandum: Jurnal Pendidikan Dasar dan Pembelajaran 8, 1 . 